\title{
PERANAN EKSPLORASI PUSTAKA UNTUK MENINGKATKAN KETRAMPILAN MENULIS PADA SISWA TUNARUNGU KELAS XI SLB PEMBINA TINGKAT NASIONAL BAGIAN C MALANG
}

\author{
Kurniati Laila, S.Pd.
}

SLB Pembina Tingkat Nasional Bagian C Malang

\begin{abstract}
Abstrak
Tujuan penelitian ini untuk mengetahui ada atau tidaknya peranan eksplorasi pustaka dalam peningkatkan ketrampilan menulis pada siswa Tunarungu khususnya kelas XI Tunarungu di SLB Pembina Tingkat Nasional Bagian C Malang. Tunarungu adalah seseorang yang mengalami gangguan pada organ pendengarannya sehingga mengakibatkan ketidakmampuan mendengar. Hambatan Pendengaran siswa tersebut berdampak pada keterampilan menulis. Salah satu untuk menunjang keterampilan menulis siswa melalui peranan Eksplorasi pustaka. Eksplorasi pustaka sebagai wadah pengembangan bidang kebahasaan dan kesastraan. Penelitian ini menggunakan Penelitian Tindakan Kelas yang terdiri dari 2 siklus. Hasil penelitian menunjukkan bahwa Kategori A mengalami kenaikan jumlah siswa sebanyak 1 siswa dan mengalami kenaikan prosentasi sebesar 4\%. Kategori B mengalami kenaikan jumlah siswa sebanyak 3 siswa dan mengalami kenaikan prosentasi sebesar 50\%. Kategori C tetap, dengan jumlah siswa sebanyak 2 siswa dengan prosentasi sebesar 33\%. Kategori D mengalami penurunan jumlah siswa sebanyak 1 siswa dan mengalami penurunan prosentasi sebesar 17\%. Kategori E mengalami penurunan jumlah siswa sebanyak 1 siswa dan mengalami penurunan prosentasi sebesar 17\%. Hasil penelitian ini menunjukkan bahwa terdapat Peranan Eksplorasi Pustaka dalam meningkatkan ketrampilan menulis pada siswa Tunarungu kelas XI SLB Pembina Tingkat Nasional Bagian C Malang
\end{abstract}

Kata kunci : Eksplorasi pustaka, keterampilan menulis, tunarungu

\section{PENDAHULUAN}

Tunarungu adalah seseorang yang mengalami gangguan pada organ pendengarannya sehingga mengakibatkan ketidakmampuan mendengar, mulai dari tingkatan yang ringan sampai yang berat sekali yang diklasifikasikan kedalam tuli (deaf) dan kurang dengar (hard of hearing). Hallan \& Kauffman (1991:266). Akibat dari ketunarunguan adalah tidak berkembangnya kemampuan berbicara, lebih dari itu dampak paling besar adalah terbatasanya kemampuan berbahasa. Mereka tidak mengenal atau mengerti lambang/kode atau nama yang digunakan lingkungan guna mewakili benda-benda, perstiswa kegiatan atau perasaan serta tidak memahami aturan/system/tata bahasa. Mereka sangat miskin akan kosa kata. Apalagi kosa kata yang bersifat abstrak.

$$
\text { Dalam struktur kurikulum }
$$
Bahasa Indonesia pada jenjang 
SMALB dalam satu minggu adalah 2 jam pelajaran. Hal ini dirasa sangat kurang dan minim sekali untuk bisa memahami dan mendapatkan pelajaran yang memadai. Untuk itulah saya berupaya untuk lebih efektif memberikan pembelajaran Bahasa Indonesia, dan akhirnya mencoba melakukan tindakan kelas

Seseorang yang selalu membaca diwaktu luang adalah ciri orang yang minat bacanya tinggi. Dengan membaca, anak akan merasa betapa banyak fenomena alam maupun lingkungan sosial yang belum mereka ketahui (Genta, 1998)

Begitu juga dengan menulis, adalah merupakan kegiatan yang mudah, hanya membutuhkan pensil dan secarik kertas. Namun tulisan yang baik memerlukan ketrampilan dan kebiasaan yang terasah dari bakat yang ada pada diri sendiri.(Genta,1998)

Dalam mengatasi permasalahan ini, penulis ingin memberikan masukan tentang Eksplorasi Pustaka sebagai wadah pengembangan bidang kebahasaan dan kesastraan. Dengan menggunakan fasilitas perpustakaan yang ada di sekolah, siswa dapat memanfaatkan perpustakaan sebagai sumber belajar, dengan begitu siswa telah melakukan pembelajaran eksplorasi terhadap lingkungannya.

Mengapa Eksplorasi Pustaka menjadi pilihan? Pertanyaan tersebut muncul ketika guru mengalami kendala dalam menyampaikan pembelajaran mengarang(menulis cerita) maupun menulis sinopsis yang sering menjadi bahan untuk lomba. Melihat hasil penulisan siswa dalam bercerita atau membuat sinopsis, sangat banyak siswa yang menulis asal jadi saja, padahal kita sebagai guru telah menyampaikan cara-cara menulis sebuah cerita dengan harapan siswa bisa menulis dengan lebih baik.

Berdasarkan latar belakang yang disampaikan, diperoleh rumusan masalah dalam penelitian ini adalah ”Bagaimana Peranan Eksplorasi Pustaka dalam meningkatkan ketrampilan menulis pada siswa Tunarungu kelas XI SLB Pembina Tingkat Nasional Bagian C Malang?”. 
Tujuan penelitian ini adalah untuk meningkatkan ketrampilan menulis pada siswa Tunarungu khususnya kelas XI Tunarungu di SLB Pembina Tingkat Nasional Bagian C Malang, Menambah semangat dan antusiasme yang tinggi pada siswa dalam mengikuti pembelajaran, Meningkatkan kreativitas dan inovasi Guru dalam menciptakan strategi pembelajaran yang tidak membosankan.

Penelitian ini diharapkan dapat bermanfaat diantaranya yaitu a|) Bagi siswa, akan lebih termotivasi untuk membaca dan menulis cerita atau karya sastra maupun pengembangan pembelajaran kebahasaan lainnya, b)Bagi Guru menjadi lebih kreatif dan inovatif dalam merencanakan pelaksanaan pembelajaran, c)Terciptanya situasi pembelajaran yang menyenangkan sehingga tidak mudah bosan, d) Menjadi masukan bagi para pembaca untuk menambah wawasan dan bagi penulis untuk memperbaiki kesalahan dan kekurangan.
Dwidjosumarto (1995, hlm. 26) mengemukakan bahwa "anak tunarungu adalah anak yang mengalami kekurangan atau kehilangan kemampuan mendengar baik sebagian atau seluruhnya yang diakibatkan karena tidak berfungsinya sebagian atau seluruh alat pendengaran, sehingga ia tidak dapat menggunakan alat pendengarannya dalam kehidupan sehari-hari yang membawa dampak terhadap kehidupannya secara kompleks.” Jadi, pengertian anak tunarungu adalah anak yang mengalami hambatan atau gangguan baik sebagian atau keseluruhan pada pendengarannya sehingga perkembangan dalam kehidupan sehari-harinya terganggu. Perkembangan kognitif pada anak tunarungu dan anak pada umumnya sama. Perkembangan kognitif anak tunarungu dipengaruhi oleh perkembangan bicara dan bahasa anak sehingga mereka cenderung mengalami keterbatasan dalam memperoleh informasi. 
Beberapa Kegiatan Eksplorasi Pustaka yang menjadi bahan pertimbangan, meliputi :

1. Siswa mengetahui beberapa bagian penting didalam perpustakaan, antara lain ruang baca, tempat menyimpan buku, dan daftar katalog buku juga harus memiliki kartu anggota perpustakaan.

2. Siswa membaca cerita dari berbagai jenis buku sesuai yang diminatinya, lalu membuat ringkasan cerita dalam bentuk karangan baru maupun sinopsis.

3. Siswa mencari referensi bacaan sebagai bahan dalam membantu menyelesaikan kesulitan belajar.

4. Siswa menjadikan perpustakaan sebagai nara sumber selain guru.

5. Siswa menjadi bagian dalam perpustakaan, yaitu siswa dilibatkan sebagai petugas perpustakaan secara bergilir. Sehingga siswa akan merasa memiliki dan akan sepenuh hati merawat kelestarian perpustakaan tersebut.
Beberapa

kelebihan

Perpustakaan antara lain:

1. Mudah didapat, karena biasanya setiap sekolah memiliki perpustakaan. Minimal mempunyai beberapa buku pelajaran yang dari tahun ke tahun dapat menjadi bahan bacaan tambahan bagi siswa.

2. Selain itu perpustakaan mudah dalam pelaksanaannya. Dalam hal ini siswa bisa meminjam untuk dibaca di tempat perpustakaan tersebut maupun dipinjam untuk dibaca di rumah. Perpustakaan sekolah itu murah. Mengapa? Karena perpustakaan memang disediakan untuk semua anggota di dalam sekolah tersebut secara gratis. Dalam hal ini siswa sebagai anggota sekolah tidak perlu membayar ketika meminjam buku.

3. Perpustakaan merupakan tempat istirahat juga. Disini suasana ketenangan harus dijaga. Dengan penataan tempat yang baik siswa dapat membaca dengan santai. Biasanya 
perpustakaan dibuka saat istirahat maupun diisi ketika ada jadwal yang kosong (sisa waktu sehabis olah raga maupun kegiatan bebas).

Tahap-tahap eksplorasi pustaka antara lain :

1. Siswa dibagi beberapa kelompok sesuai tema cerita yang ada pada Katalog perpustakaan.

2. Siswa memilih cerita dengan cara meminjam ke perpustakaan.

3. Siswa mendiskusikan dengan temannya judul cerita masingmasing agar tidak sama tetapi sesuai tema yang telah ditentukan.

4. Siswa menukar hasil karya cerita masing-masing untuk mengoreksi dan menunjuk salah satu temannya untuk membaca kembali. Maksud dan tujuannya adalah cerita tersebut merupakan hasil karya anak dan sesuai dengan selera anak maka yang menjadi pembanding adalah anak.
5. Hasil cerita dievaluasi secara proses dan evaluasi akhir, karena guru selain bertindak sebagai fasilitator dan nara sumber harus melakukan penilaian.

\section{METODE}

Penelitian ini merupakan penelitian tindakan (action research), karena penelitian dilakukan untuk memecahkan masalah pembelajaran di kelas. Penelitian ini juga termasuk penelitian deskriptif, sebab menggambarkan bagaimana suatu teknik pembelajaran diterapkan dan bagaimana hasil yang diinginkan dapat dicapai.

Model penelitian tindakan kelas berupa rangkaian siklus yang terdiri empat tahapan yaitu perencanaan (tindakan mempersiapkan semua instrumen, sarana, dan semua yang diperlukan dalam penelitian tindakan.), tindakan (tindakan yang dilaksanakan sesuai dengan RPP), observasi (pengamatan terhadap aktivitas anak dari setiap indikator kegiatan anak tunarungu), refleksi (kegiatan menganalisa, menjelaskan informasi 
dari hasil pelaksanaan tindakan, yaitu hasil observasi). Jika pada siklus pertama belum didapatkan hasil yang maksimal maka akan dilanjutkan pada siklus-siklus selanjutnya hingga mencapai ketentuan yang ditentukan (berhasil).

Dalam penelitian ini menggunakan bentuk guru sebagai peneliti, dimana guru sangat berperan sekali dalam proses penelitian tindakan kelas. Dalam bentuk ini, tujuan utama penelitian tindakan Kelas XI Tunarungu Siswa kelas SLB Pembina Tingkat Nasional Bagian C Malang Tahun Ajaran 2020-2021. Dalam kegiatan ini, guru terlibat langsung secara penuh dalam proses perencanaan, tindakan, observasi, dan refleksi. Kehadiran pihak lain dalam penelitian ini peranannya tidak dominan dan sangat kecil.

Metode pengumpulan data adalah cara yang digunakan dalam mengumpulkan data, seperti melalui observasi (pengamatan yang dilakukan dalam proses kegiatan), tes (memperhatikan nilai yang diperoleh untuk mencapai tujuan pembelajaran yang diinginkan menggunakan hasil tes anak tunarungu)

Setelah sejumlah data dalam penelitian terkumpul maka kesimpulan diperoleh melalui teknik analisa data. Dalam proses penelitian tindakan kelas, analisa data yang digunakan dalam penelitian ini adalah refleksi berdasarkan siklus-siklus penelitian tindakan kelas.

\section{HASIL DAN PEMBAHASAN}

Dari data diketahui pada siklus I yang tidak memenuhi batas tuntas minimal (6.5) ada 2 orang

Tabel 1. Siklus I

\begin{tabular}{|c|c|}
\hline NILAI & $\begin{array}{c}\text { JUMLAH } \\
\text { SISWA }\end{array}$ \\
\hline $\mathrm{A}=9.0-9.9$ & 0 \\
\hline $\mathrm{B}=8.0-8.9$ & 2 \\
\hline $\mathrm{C}=7.0-7.9$ & 2 \\
\hline $\mathrm{D}=6.0-6.9$ & 1 \\
\hline $\mathrm{E}<6.0$ & 1 \\
\hline $\begin{array}{c}\text { TOTAL JUMLAH } \\
\text { SISWA }=\end{array}$ & 6 \\
\hline
\end{tabular}

Tabel 2. Siklus II

\begin{tabular}{|c|c|}
\hline NILAI & $\begin{array}{c}\text { JUMLAH } \\
\text { SISWA }\end{array}$ \\
\hline $\mathrm{A}=9.0-9.9$ & 1 \\
\hline $\mathrm{B}=8.0-8.9$ & 3 \\
\hline $\mathrm{C}=7.0-7.9$ & 2 \\
\hline $\mathrm{D}=6.0-6.9$ & 0 \\
\hline $\mathrm{E}<6.0$ & 0 \\
\hline $\begin{array}{c}\text { TOTAL JUMLAH } \\
\text { SISWA }=\end{array}$ & 6 \\
\hline
\end{tabular}


Tabel 3. Prosentase Pencapaian Target

\begin{tabular}{|c|c|c|c|c|c|c|}
\hline $\begin{array}{c}\text { N } \\
\text { o }\end{array}$ & $\begin{array}{c}\text { Kateg } \\
\text { ori }\end{array}$ & \multicolumn{2}{|c|}{ Siklus I } & \multicolumn{2}{c|}{ Siklus Ii } & Keterangan \\
\hline & & OR & PER & O & PER & \\
& & $\begin{array}{c}\text { G } \\
\text { SEN }\end{array}$ & $\begin{array}{c}\text { RE } \\
\text { G }\end{array}$ & \\
\hline 1 & $\mathrm{~A}=$ & 0 & $0 \%$ & 1 & $17 \%$ & Meningkat \\
\hline 2 & $\mathrm{~B}=$ & 2 & $33 \%$ & 3 & $50 \%$ & Meningkat \\
\hline 3 & $\mathrm{C}=$ & 2 & $33 \%$ & 2 & $\begin{array}{c}33 \\
\%\end{array}$ & Tetap \\
\hline 4 & $\mathrm{D}=$ & 1 & $17 \%$ & 0 & $0 \%$ & Menurun \\
\hline 5 & $\mathrm{E}=$ & 1 & $17 \%$ & 0 & $0 \%$ & Menurun \\
\hline
\end{tabular}

Diskripsi hasil prosentase :

1. Kategori A mengalami kenaikan jumlah siswa sebanyak 1 siswa dan mengalami kenaikan prosentasi sebesar 4\%.

2. Kategori B mengalami kenaikan jumlah siswa sebanyak 3 siswa dan mengalami kenaikan prosentasi sebesar 50\%.

3. Kategori $\mathrm{C}$ tetap, dengan jumlah siswa sebanyak 2 siswa dengan prosentasi sebesar 33\%.

4. Kategori D mengalami penurunan jumlah siswa sebanyak 1 siswa dan mengalami penurunan prosentasi sebesar $17 \%$.

5. Kategori E mengalami penurunan jumlah siswa sebanyak 1 siswa dan mengalami penurunan prosentasi sebesar $17 \%$
Grafik Peningkatan Pembelajaran Pada Siklus I Dan II

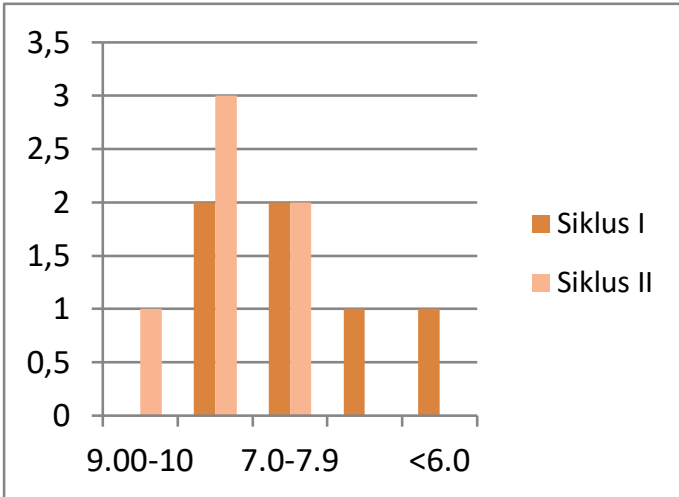

Deskripsi Temuan

Pada Siklus I, hasil pembelajaran kurang memuaskan karena masih banyak siswa yang memiliki nilai ratarata 6,0-6,9, antara lain disebabkan:

a. Anak hanya terpaku pada bacaan cerita yang ada pada bacaan buku pelajaran (tidak ada alternatif pilihan yang lain yang menjadi kesukaan anak).

b. Anak kurang tertarik karena ceritanya membosankan (tidak ditunjang dengan gambar yang menarik)

c. Metode pembelajaran yang berupa pemberian tugas dari guru, kurang begitu menantang, karena dalam pemberian tugas, anak hanya terdoktrin harus mengerjakan tugas tersebut tanpa dapat menyalurkan semua kemampuan bakat dan minatnya dalam membaca dan menulis cerita sederhana.

Namun setelah diadakan Siklus II, dengan memakai kegiatan eksplorasi pustaka, siswa mengalami perubahan 
peningkatan, terbukti pada kenaikan jumlah siswa yang mendapat nilai ratarata $9,0-9,9 ; 8,0-8,9 ; 7,0-7,9$ dan penurunan jumlah siswa yang mempunyai nilai rata-rata 6,0-6,9 dan kurang dari 6,0.

Kegiatan eksplorasi pustaka sangat membantu siswa untuk terjun langsung dengan lingkungannya. Hal-hal yang dapat langsung diperoleh antara lain:

a. Pengalaman tak terlupakan ketika siswa menemukan cerita lalu memahami isi bacaan yang disukainya.

b. Siswa dengan leluasa menikmati bacaan dengan suasana tenang dan santai

c. Siswa dapat menemukan nara sumber lain bila menemukan kesulitan, ini menunjukkan bahwa siswa memiliki rasa ingin tahu yang besar.

Dari segi guru, kegiatan eksplorasi pustaka merupakan ide kreatif dan inovatif dalam merencanakan pelaksanaan pembelajaran. Guru hanya berperan sebagai fasilitator dan siswalah yang aktif melakukan kegiatan.

Dari segi siswa, kegiatan eksplorasi pustaka banyak membantu siswa mempelajari karya fiksi maupun non fiiksi, guna mengembangkan dan meningkatkan minat membaca dan menulis. Selain itu suasana kelas tampak lebih aktif karena siswa lebih responsif. Selain itu siswa akan mendapat pengalaman secara langsung dan tidak terlupakan. Minat dan bakat siswa dapat tergali melalui kegiatan eksplorasi yang secara tidak langsung merangsang siswa untuk mempunyai rasa ingin tahu yang besar. Sehingga akan tampak perubahan perkembangan yang sangat mencolok pada diri siswa.

\section{PENUTUP}

\section{Simpulan}

Penelitian ini menggunakan Penelitian Tindakan Kelas (PTK) yang dilaksanakan sebanyak tiga siklus yaitu siklus I, siklus II. Pada setiap siklusnya terdiri dari perencanaan, pelaksanaan tindakan, observasi, dan refleksi. Kegiatan Pembelajaran yang dilakukan guru bilamana belum mencapai batas ketuntasan menuntut guru untuk melakukan perbaikan pembelajaran. Hal ini dapat dipastikan ketidakberhasilan tersebut karena kurang optimalnya guru melibatkan instrumen pembelajaran dan kurangnya inovasi dan kreativitas dalam menciptakan suasana pembelajaran yang lebih menyenangkan dan memberi pengalaman baru kepada siswa.

Secara umum dapat ditarik kesimpulan sebagai berikut :

1. Keberhasilan siswa dapat ditingkatkan karena guru dapat merancang strategi pembelajarannya secara tepat.

2. Keaktifan siswa dalam mengikuti pelajaran 
meningkat karena guru memilih dan menciptakan metode secara kreatif dan inovatif sehingga tidak membosankan.

3. Kemampuan, kreativitas dan profesionalitas guru teruji setelah melakukan kegiatan perbaikan pembelajaran dengan hasil yang memuaskan.

4. Kegiatan Eksplorasi pustaka dapat menumbuhkan minat pada siswa dalam membaca dan menulis.

5. Kegiatan pembelajaran yang menyenangkan dapat tercipta.

\section{Saran}

Berdasarkan kesimpulan tersebut, beberapa hal sebaiknya dilakukan oleh guru dalam meningkatkan kualitas pembelajaran. Antara lain adalah :

1. Menyusun rencana perbaikan pembelajaran yang tepat dan memuat berbagai instrumen pembelajaran yang dapat menunjang keberhasilan pelaksanaan pembelajaran secara maksimal dan memuaskan.

2. Menciptakan model pembelajaran yang menyenangkan dengan menggunakan metode secara kreatif dan inovatif serta dapat meningkatkan keaktifan dan kemampuan siswa untuk mencapai nilai batas ketuntasan dalam kegiatan pembelajarannya.

3. Menggunakan strategi pembelajaran yang terencana yang dapat memotivasi siswa untuk menemukan pengalamannya sendiri.

4. Guru harus dapat bersikap profesional apabila dalam pelaksanaan kegiatan pembelajarannya kurang berhasil dengan melakukan kegiatan perbaikan pembelajaran yang lebih baik.

\section{DAFTAR PUSTAKA}

Andayani, dkk. (2007). Pemantapan Kemampuan Profesional (Panduan). Jakarta : Universitas Terbuka

Dwidjosumarto, A. (1995). Ortopedagogik anak tunarungu. Bandung: Direktorat Jenderal Pendidikan Tinggi departemen Pendidikan dan Kebudayaan.

Joan, Beck. (2003). Meningkatkan Kecerdasan Anak. Jakarta : Delapratasa.

Suprayekti, dkk. (2005). Pembaharuan Pembelajaran di SD. Jakarta : Universtas Terbuka.

Suparno. (2003). Ketrampilan Dasar Menulis. Jakarta : Universitas Terbuka.

Wardani, I.G.A.K. (2003). Penelitian Tindakan Kelas. Jakarta: Universitas Terbuka. 